\title{
Primary malignant orbit melanoma
}

\section{Lucas Gomes Patrocínio ${ }^{1}$, Clauber Lourenço ${ }^{2}$, Cristiane do Prado Silva ${ }^{3}$, Daniela Borges Barra ${ }^{4}$, José Antônio Patrocínio $^{5}$}

\section{INTRODUCTION}

The first case of extracutaneous melanoma was described in Germany (1856) and up until 2001 approximately 1000 cases had been published ${ }^{1,2}$. These are rare lesions, representing about $0.09 \%$ of the extracutaneous malignant neoplasias1. In the orbit, it is frequently secondary to invasions by conjunctiva, choroid melanomas or from adjacent regions, or blood-born metastases ${ }^{3}$. The primary orbital melanoma represents less than $1 \%$ of the primary orbital neoplasias ${ }^{4}$.

\section{CASE REPORT}

O.S.S., female, 64 years old, presented progressive ptosis, visual blurring and right eye scotomatas for two months. Did not present with any otorhinolaryngological complaint. She had proptosis, visual acuity for hands movement, papilledema and extrinsic muscle paralysis to the right side; without alterations noticed at the nasofibroscopy.

CT scan showed a right side retroorbital tumor (Figure 1aa ); transconjunctival biopsy (inferior fornix) showed malignant melanoma. Skull, chest and abdomen CT scan did not find other involvements.

Right side exenteration was carried

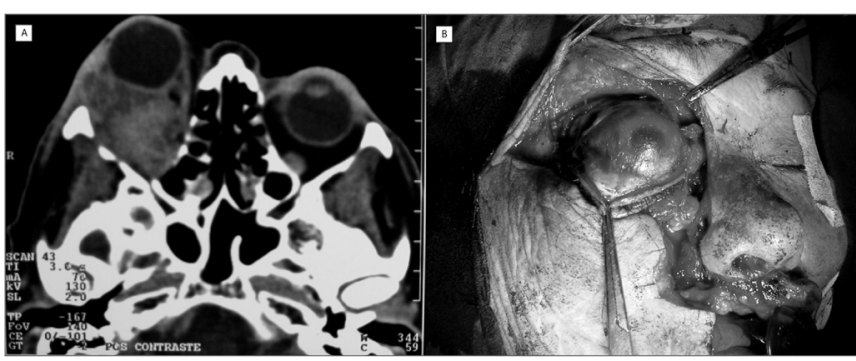

Figure 1. Photography showing an orbit primary melanoma in a CT Scan axial view (A) and during exenteration of the right orbit via broadened Weber-Fergusson incision towards the eyebrow region $(\mathrm{B})$ out through a Weber-Fergusson incision broadened towards the eyebrow region (Figure 1b). Histopathology proved that there was no invasion of eye tissue or the optic nerve, without invasion of adjacent structures and free margins.

Four weeks later, radiotherapy started, with 30 applications of 180 cGy. The patient has been followed for 18 months now, with periodic CT scans used for the early identification of metastases or local recurrence.

\section{DISCUSSION}

Extracutaneous melanomas are neoplasias that affect the elderly. Series of primary orbital melanomas show ages varying between 12 and 84 years $^{3,5}$. There are only two cases of African-descendant patients $^{3-5}$

Orbital primary melanomas are probably originated from the congenital remains of cells from the neural crest, and may be found along ciliary nerve, scleral emissary veins or the leptomeninx of the optical nerve ${ }^{3-6}$. Due to the small number of cases, there is not much data regarding its clinical behavior, however, the most common clinical presentation is pain-associated proptosis originated from a diffuse orbital mass 4 For diagnostic confirmation it is necessary to have biopsy and immunephenotyping1. In order to define whether the orbital melanoma is primary, it is necessary to show, though image and pathology exams, that it did not originate from the eye globe and it does not represent a metastasis $3,5,6$ Differential diagnosis must be made with benign and malignant tumors of the nose, the paranasal cavities, orbit, and skull base, specially vascular anomalies and pigmentary schwannomas.

Treatment of choice is based on exenteration, that is, complete removal of the orbital content, including the eyeball and eyelids. Radiotherapy and chemotherapy have been used as additional treatment, with uncertain results. ${ }^{3-5}$.

\section{FINAL COMMENTS}

The orbit primary melanoma is a tumor of rare occurrence; however it is most of the times fatal. We stress the need to carry out strict clinical and image exams, and specially biopsy followed by immunephenotyping when facing a case of subacute proptosis.

\section{REFERENCES}

1.Minerva L, Suárez N, López L. Melanoma extracutáneo de cabeza y cuello. Estudio clínico patológico de 19 casos. Rev Méd Hosp Gen Méx 2001;64(3):131-6.

2.Manolidis S, Donald PJ. Malignant mucosal melanoma of the head and neck: review of the literature and report of 14 patients. Cancer 1997;80(8):1373-86.

3Tellada M, Specht CS, McLean IW, Grossniklaus HE, Zimmerman LE. Primary orbital melanomas. Ophthalmology 1996;103(6):929-32.

4.Elibol O, Yuksel N, Egilmez HR, Arici S, Mizrak B. A case of primary orbital melanoma treated by local excision. Br J Ophthalmol 1995;79(12):1146-8.

5.Schultz AB, Hunter S, Grossniklaus HE. Primary melanocytic tumor of the orbit and central nervous system. Ophthalmol Clin North Am 1996;9(4):705-20

6.Marback RL et al. Melanoma maligno da órbita após evisceração. Rev Bras Oftalmol 1995;54(7): 53-7.

\footnotetext{
${ }^{1}$ MD. Otorhinolaryngology Resident - Federal University of Uberlândia. Medical Student - Medical School - Federal University of Uberlândia. Medical Student - Medical School - Federl University of Ubelanndia. Medical Student - Medical School - Federal University of Uberlândia. Full Professor of Otorhinolaryngology - Medical School - Federal University of Uberlândia. Department of Otorhinolaryngology - Medical School - Federal University of Uberlândia, Minas Gerais Mailing Address: Lucas Gomes Patrocínio - Rua XV de Novembro 327 apto. 1600 Bairro Centro Uberlândia MG 38400-214. Tel/Fax: (0xx34) 3215-1143 - E-mail: lucaspatrocinio@triang com.br

Paper submitted to the ABORL-CCF SGP (Management Publications System) on March 11th, 2005 and accepted for publication on May 1st, 2006. Cod. 112.
} 